\title{
Lacustrine spawning by mountain suckers (Catostomus platyrhynchus) on Boulder Mountain, Utah
}

\author{
Martin C. Arosteguil,* \\ ${ }^{1}$ School of Aquatic and Fishery Sciences, Box 355020, University of Washington, Seattle, WA 98195
}

\begin{abstract}
Facultative spawning in lakes is an uncommon and notable behavior among catostomids and other fish species that typically spawn in streams. I describe what may be the first documented case of lake-spawning behavior by mountain suckers (Catostomus platyrhynchus).
\end{abstract}

RESUMEN.-El desove facultativo en los lagos es un comportamiento poco común y notable entre los catostomidos y otras especies de peces que típicamente desovan en los arroyos. Describo cuál puede ser el primer caso documentado del comportamiento de desove en un lago por los matalotes del montaña (Catostomus platyrhynchus).

Facultative spawning in lakes is an uncommon and notable behavior among catostomids (Billman 2008) and other fish species that typically spawn in streams (e.g., Cowan and Baggs 1988). Mountain suckers (Catostomus platyrhynchus) are thought to spawn only in fluvial habitats, as most populations live exclusively in streams (Hauser 1969, reviewed in Belica and Nibbelink 2006). Populations that live in lakes or reservoirs migrate into tributary inlet streams to spawn (Decker and Erman 1992, Wydoski and Wydoski 2002). Here, I describe what may be the first documented case of lake-spawning behavior by mountain suckers.

Blind Lake is a small alpine lake (surface area $0.2 \mathrm{~km}^{2}$, mean depth $13 \mathrm{~m}$, max depth $23 \mathrm{~m}$, elevation $3119 \mathrm{~m}$ ) on the north slope of Boulder Mountain, Utah $\left(38^{\circ} 10^{\prime} 36.51^{\prime \prime} \mathrm{N}\right.$ $\left.111^{\circ} 26^{\prime} 33.59^{\prime \prime} \mathrm{W}\right)$ (UDWR unpublished data). During years with pronounced rainfall, water from the mountaintop may flow into and out of the lake; however, such conditions rarely occur, and the resulting flows do not constitute viable spawning streams (R. Hepworth, Utah Division of Wildlife Resources, personal communication). Mountain suckers are not native to this lake but have been present since their unauthorized introduction sometime prior to 1980 (R. Hepworth personal communication) and possibly even before the early 1950s (UDWR unpublished data). In Blind Lake, they co-occur with splake (Salvelinus namaycush $q \times S$. fontinalis $\hat{0})$, brook trout (S. fontinalis), Arctic grayling (Thymallus arcticus), Colorado River cutthroat trout (Oncorhynchus clarkii pleuriticus), and rainbow trout (O. mykiss) (UDWR 2015). All of the aforementioned salmonids are stocked for recreational fisheries except brook trout that spawn in the lake and constitute a self-sustaining population (R. Hepworth personal communication; UDWR unpublished data).

Multiple spawning aggregations of mountain sucker were observed in mid-June (2013) near shore in the northeast corner of the lake over rocky substrate at $<1.5 \mathrm{~m}$ depth. Sexually mature males were olive green dorsally, white ventrally, and exhibited bright orange and black lateral stripes. In contrast, females were mostly brown with a less pronounced reddish lateral stripe. Males were smaller than females ( 150 vs. $200 \mathrm{~mm}$ TL) and exhibited pronounced tubercles (Figs. 1, 2), matching descriptions by other authors (Hauser 1969, Baxter and Stone 1995). Aggregations typically consisted of 8 to 10 males competing for proximity to a single female (Figs. 1, 2), consistent with spawning behavior of cui-ui (Chasmistes cujus-Koch 1973), June sucker (Chasmistes liorus_Billman 2008), and razorback sucker

*Corresponding author: marosteg@uw.edu

MCA

orcid.org/0000-0002-9313-9487 


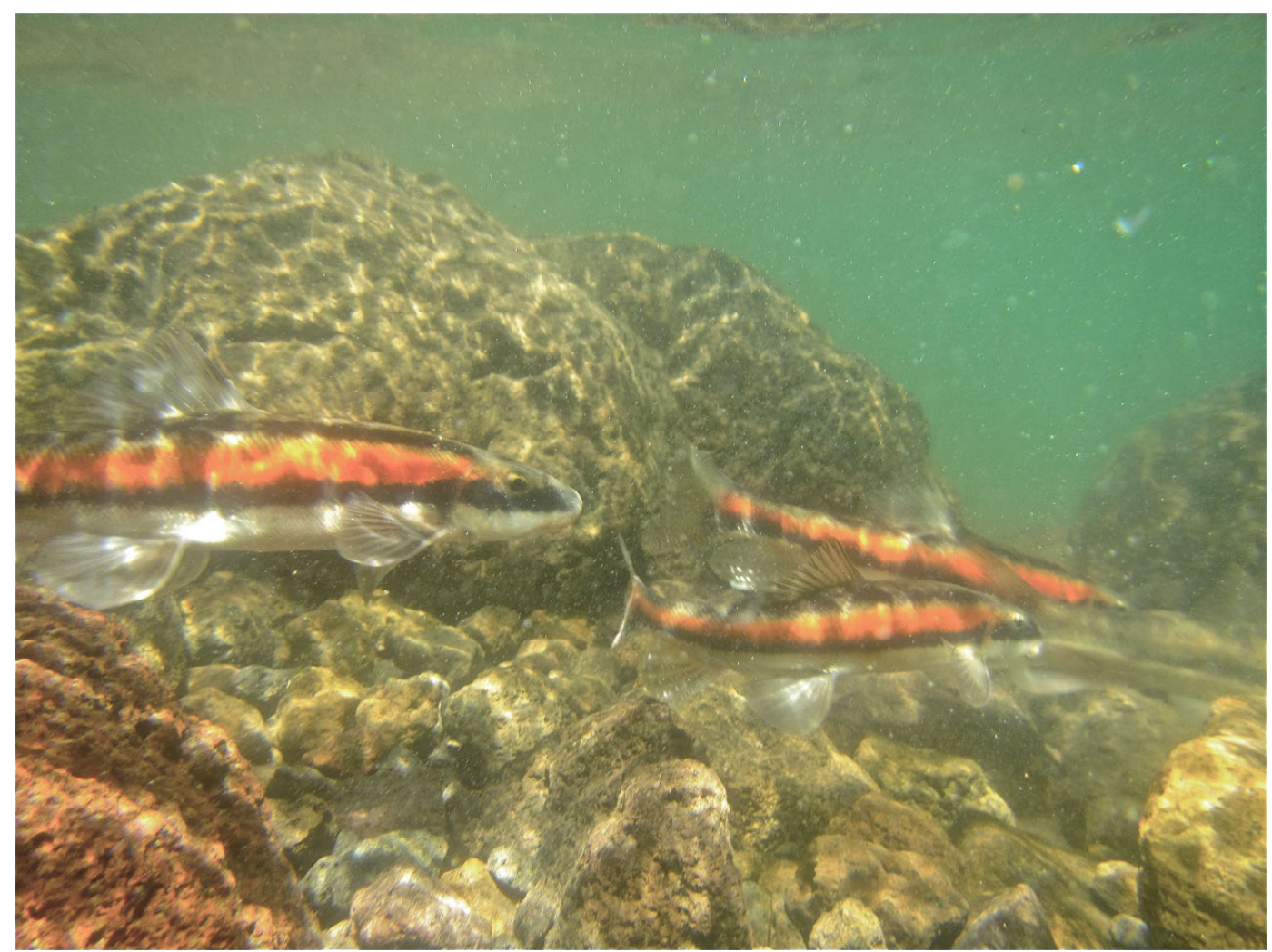

Fig. 1. Aggregation of mountain sucker males in spawning coloration and with tubercles; the males are competing for proximity to the brown female (far right, only posterior visible). Photo by Martin C. Arostegui.

(Xyrauchen texamus-Bozek et al. 1991) in lacustrine habitats. Although a given aggregation was constantly moving while males chased the female, its movements were largely restricted to a small area. For example, the photographed aggregation was engaged in courtship activity for nearly an hour along the same approximately $4 \mathrm{~m}$ of shoreline. Individual males occasionally left the aggregation and exhibited diminished movement and speed, sometimes foraging on the bottom for a short period of time before rejoining the group and jockeying for position near the female. Though the moment of gamete deposition was not witnessed, a limited number of eggs were seen on the substrate and suspended in mid-water in the immediate vicinity of the photographed spawners (Fig. 2). More aggregations appeared along the shoreline as the day progressed, suggesting that spawning may not occur at night or at least is primarily diurnal. Immature fish (those without spawning coloration) were not observed along the lakeshore and, presumably, confined their distribution to deeper waters.

The early summer spawning observed in Blind Lake is within the typical spawning season documented for the species (reviewed in Belica and Nibbelink 2006). Additionally, large populations of nonnative mountain sucker were formerly present in nearby Fish Creek Reservoir and Beaver Dam Reservoir (Chamberlain 2000), where spawning aggregations occurred along shorelines during the summer prior to their extirpation by rotenone treatment (R. Hepworth personal communication). Interestingly, Baxter and Stone (1995) noted male and female mountain suckers in spawning coloration along the shore of an unnamed alpine lake in the Wind River Mountains, Wyoming, but they specifically stated that no spawning was observed.

Lacustrine spawning by mountain sucker is likely possible due to the presence of groundwater upwelling. Brook trout, but no other 


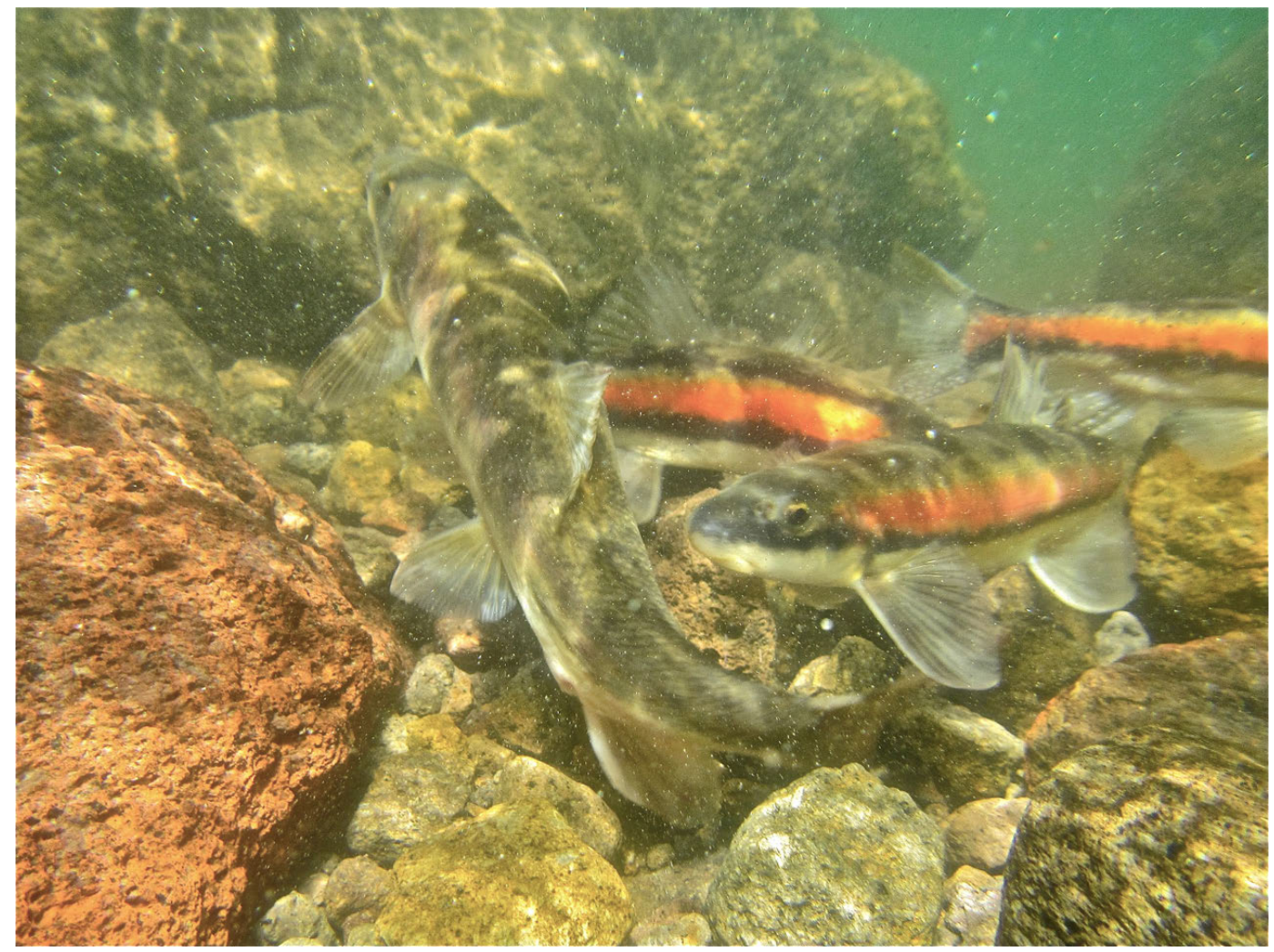

Fig. 2. Mountain sucker males (right) approaching a female (left) that is orienting its vent toward the substrate. Note the suspended, whitish egg beneath the head of the proximal male. Photo by Martin C. Arostegui.

sympatric salmonids, successfully reproduce in upwelling areas of Blind Lake and do not require annual stocking (R. Hepworth personal communication). Groundwater upwelling enables lakeshore spawning by a number of salmonid species that typically spawn in streams (e.g., sockeye salmon [Oncorhynchus nerka]_Burger et al. 1995, brook troutBlanchfield and Ridgway 1997, brown trout [Salmo trutta]-Brabrand et al. 2002). The capacity for spawning in lacustrine as opposed to fluvial habitats may be associated with adaptive genetic divergence of distinct intraspecific ecotypes (e.g., Larson et al. 2014, 2017), and efforts should be made to identify and study mountain sucker populations spawning in lakes within the species' native range.

\section{ACKNOWLEDGMENTS}

Many thanks to Richard Hepworth for sharing his invaluable knowledge of Boulder
Mountain and its fish, both Richard Hepworth and Thomas Quinn for reviewing the manuscript prior to submission, and Mark Belk and an anonymous reviewer for providing constructive feedback that improved the manuscript. Funding for me as a PhD student was provided by the Clarence H. Campbell Endowed Lauren Donaldson Scholarship in Ocean and Fishery Sciences, the Achievement Rewards for College Scientists (ARCS) Foundation Seattle Chapter via the Barton Family, the H. Mason Keeler Endowment, the Richard T. Whiteleather Fisheries B.S. 1935 Endowed Scholarship, and the Floyd E. Ellis Memorial Scholarship. Because this was an observational study, a scientific permit was not required by the Utah Division of Wildlife Resources.

\section{Literature Cited}

BaXter, G.T., AND M.D. Stone. 1995. Fishes of Wyoming. Wyoming Game and Fish Department, Cheyenne, WY. 
BelicA, L.T., AND N.P. NibBELINK. 2006. Mountain sucker (Catostomus platyrhynchus): a technical conservation assessment. USDA Forest Service, Rocky Mountain Region.

Billman, E.J. 2008. Reproduction by June sucker in a refuge population: successful spawning in a lake habitat. Western North American Naturalist 68: 475-482.

BlanchField, P.J., and M.S. Ridgway. 1997. Reproductive timing and use of redd sites by lake-spawning brook trout (Salvelinus fontinalis). Canadian Journal of Fisheries and Aquatic Sciences 54:747-756.

Bozek, M.A., L.J. Paulson, G.R. Wilde, and J.E. DeaCON. 1991. Spawning season of the razorback sucker, Xyrauchen texanus in Lake Mohave, Arizona and Nevada. Journal of Freshwater Ecology 6:61-73.

Brabrand, Å., A.G. Koestler, and R. Borgstrøm. 2002. Lake spawning of brown trout related to groundwater influx. Journal of Fish Biology 60:751-763.

Burger, C.V., J.E. Finn, and L. Holland-Bartels. 1995. Pattern of shoreline spawning by sockeye salmon in a glacially turbid lake: evidence for subpopulation differentiation. Transactions of the American Fisheries Society 124:1-15.

Chamberlain, C. 2000. Environmental assessment for sport fish enhancement projects on the Boulder Mountains. Unpublished report. Utah Division of Wildlife Resources, Southern Region Office, Cedar City, UT.

CowAN, G.I. MCT., AND E.M. BAGGS. 1988. Incidences of lacustrine spawning of the ouananiche, Salmo salar, and the brook charr, Salvelinus fontinalis, on the Avalon Peninsula, Newfoundland. Journal of Fish Biology 32:311-312.

Decker, L.M., AND D.C. Erman. 1992. Short-term seasonal changes in composition and abundance of fish in
Sagehen Creek, California. Transactions of the American Fisheries Society 121:297-306.

Hauser, W.J. 1969. Life history of the mountain sucker, Catostomus platyrhynchus, in Montana. Transactions of the American Fisheries Society 98:209-215.

KocH, D.L. 1973. Reproductive characteristics of the Cui-ui lakesucker (Chasmistes cujus Cope) and its spawning behavior in Pyramid Lake, Nevada. Transactions of the American Fisheries Society 102: 145-149.

Larson, W.A., M.T. Limborg, G.J. McKinney, D.E. Schindler, J.E. Seeb, and L.W. Seeb. 2017. Genomic islands of divergence linked to ecotypic variation in sockeye salmon. Molecular Ecology 26:554-570.

Larson, W.A., J.E. Seeb, T.H. Dann, D.E. Schindler, AND L.W. SEEB. 2014. Signals of heterogeneous selection at an MHC locus in geographically proximate ecotypes of sockeye salmon. Molecular Ecology 23:5448-5461.

[UDWR] Utah Division of Wildlife Resources. 2015. Fishing Boulder Mountain: a Utah blue ribbon fishing destination. https://wildlife.utah.gov/pdf/b-mtn .pdf

Wydoski, R.G., AND R.S. Wydoski. 2002. Age, growth, and reproduction of mountain suckers in Lost Creek Reservoir, Utah. Transactions of the American Fisheries Society 131:320-328.

Received 17 January 2018 Revised 28 April 2018 Accepted 2 May 2018 Published online 3 July 2018 